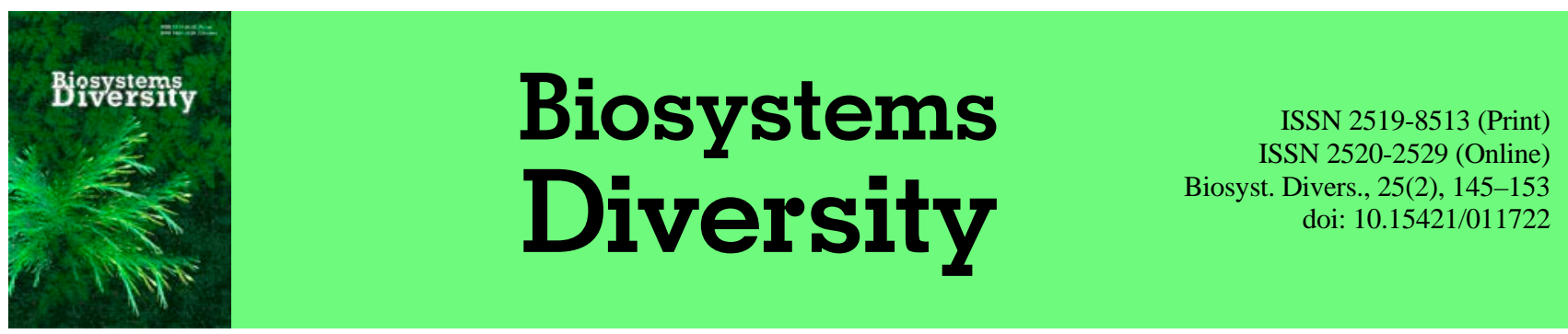

\title{
The distribution of heavy metals content in the bottom deposits of the trans-border Uzh river system
}

\author{
M. V. Bilkey, V. I. Nikolaichuk \\ Uzhgorod National University, Uzhgorod, Ukraine
}

Article info

Received 12.04.2017

Received in revised form 14.05.2017

Accepted 16.05.2017

Uzhgorod National University, Voloshyn Str., 32,

Uzhgorod, 88000, Ukraine.

Tel.: +38-099-432-43-77.

E-mail:mariannabilkei@ukr.net
Bilkey, M. V., \& Nikolaichuk, V. I. (2017). The distribution of heavy metals content in the bottom deposits of the
trans-border Uzh river system. Biosystems Diversity, 25(2), 145-153. doi:10.15421/011722

The dynamics and peculiarities of the heavy metals $(\mathrm{Cu}, \mathrm{Pb}, \mathrm{Zn}, \mathrm{As}, \mathrm{V}, \mathrm{Cr}, \mathrm{Ni})$ migration were established in the system of the river Uzh bottom deposits. An excess in maximum permissible concentration among such elements as Zn, $\mathrm{V}$, As, and $\mathrm{Cu}$ was detected in surface waters. We may connect the elevated level of $\mathrm{Cu}$ and $\mathrm{Zn}$ with natural (metals appearing in ground water run-off, ablation from iron ore, the reaction of interstitial water), anthropogenic (sewage disposals from communal households and manufacturing plants, agricultural run-offs), and hydrochemical ( $\mathrm{pH}$ of water medium, methylation of non-organic metal compounds, metals release from the organic compounds composition, ingress from bottom deposits) factors. The high concentrations of vanadium in the water as well as in bottom deposits are most probably induced by the leaching of elements from the regional volcanic rocks. The plumbum content did not exceed the higher-than-normal rates; however, significant element accumulation was detected in bottom deposits outside the city of Uzhgorod which may be the result of ecotoxicant ingress along with land runoff from the riverside highways laid parallel to the water course. In comparison with background measures, the highest chromium and nickel concentrations were detected near the streamlet Domoradzh and, therefore, it is assumed that the industrial wastewaters serve here as a source of heavy metals. The reservoir in the lowland is above all enriched by arsenic. Areas under agricultural use are significantly concentrated in lowlands. Runoffs from these areas are the main source of the ore supply. However, the impact of municipal domestic waste water which contains arsenic-containing detergents should not be excluded. Moreover, we found a relationship between the relief heterogeneity of the study area and distribution of heavy metals in the hydro-ecosystem. The accomplished comparative analysis of the territories under study indicates the significant pollution level of the surface waters in technologically transformed areas, whereas the largest accumulation of pollutants is concentrated in bottom deposits of the river, which indicates a constant supply of pollutants to the streamflow.

Keywords: anthropogenic pressure; bottom deposits; hydro-ecosystem; threshold limit value

\section{Розподіл вмісту важких металів у системі «вода - донні відкладення» транскордонної річки Уж}

\author{
М. В. Білкей, В. І. Ніколайчук
}

\section{Ужсгородський націіональний університет, Ужсгород, Украӥна}

Встановлено динаміку та особливості міграції важких металів (Cu, Pb, Zn, As, V, Cr, Ni) у системі «вода - донні відклади» річки Уж. У поверхневих водах зафіксовано перевищення ГДК для таких елементів, як Zn, V, As та Сu. Підвищений вміст купруму та цинку пов'язуємо з природньми (вимивання з гірських порід, реакція грунтового розчину), антропогенними (стічні води комунально-побутових господарств, промислових підприємств, сільськогосподарські стоки) та гідрохімічними (рН водного середовища, вивільнення металів зі складу органічних сполук, їх надходження з донних відкладів) факторами. Високі концентрації ванадію як у воді, так і в донних відкладах найімовірніше спричинені вимиванням елемента з вулканічних гірських порід, поширених у даній області. Вміст плюмбуму не перевищував наднормативних значень, однак виявлена значна акумуляція елементу в донних відкладах за межами міста Ужгород, що може бути наслідком надходження екотоксиканта з поверхневим стоком із прибережних автосмуг, прокладених паралельно водотоку. Порівняно з фоновими показниками найвищі концентрації хрому та нікелю зафіксовано неподалік від струмка Доморадж, тому припускаємо, що джерелом важких металів тут виступають промислові стічні води. Арсеном найбільш збагачена водойма в пониззі, де зосереджено чимало сільськогосподарських угідь, змиви з яких - основне джерело надходження металу. Здійснено порівняльний аналіз досліджуваних територій, який указує на значний рівень забруднення поверхневих вод у районі техногенно трансформованої території, тоді як найбільша акумуляція полютантів зосереджена в донних відкладах пониззя річки, що свідчить про регулярне надходження забруднюючих речовин до водотоку.

Ключові слова: антропогенне навантаження; донні відклади; гідроекосистема; гранично допустима концентрація 


\section{Вступ}

Нині одна з основних екологічних проблем - забруднення поверхневих вод (Islam et al., 2015; Mohiuddin, et al., 2016). Інтенсифікація антропогенного навантаження в сукупності 3 природно-кліматичними факторами викликає значні зміни у структурі гідроекосистем, які супроводжуються порушенням гідрологічного та гідрохімічного режимів, біотрансформацією екотоксикантів та їх акумуляцією в ланцюгах живлення, кінцева ланка яких - людина та тварини (Bo et al., 2014; Götze et al., 2014; Brygadyrenko and Ivanyshyn, 2015; Kul'bachko et al., 2015; Tsvetkova et al., 2016). До одних із найнебезпечніших забруднювачів водних об'єктів належать важкі метали (Fujita et al., 2014; Shakeri et al., 2016). Здатність важких металів до біоакамуляції часто спричинює безповоротні зміни як на організменному, так і на клітинному рівні (Cirillo et al., 2011; Al-Shami et al., 2012). За дії важких металів знижується репродуктивна здатність гідробіонтів, уповільнюється їх ріст та підвищується рівень захворюваності (Sfakianakis et al., 2015). Тривалий токсичний вплив важких металів зкмовлює структурні перебудови у гідробіологічній системі, змінюється видовий склад мікроорганізмів, порушуються механізми природного самоочищення водойм (Zhu et al., 2013; Yu et al., 2015).

Надходження важких металів до водойм відбувається двома основними шляхами: природним і антропогенним. Природне забруднення здебільшого спричинене протіканням геохімічних процесів: ерозією, вулканічної діяльністю, вивітрюванням гірських порід та мінералів тощо (Grba et al., 2015). Техногенний вплив супроводжується перенасиченням водних об'єктів промисловими та комунальними стоками, забрудненими атмосферними опадами, надмірною хімізацією сільськогосподарських полів, нагромадженням великої кількості твердих побутових відходів, видобутком корисних копалин і багатьма іншими факторами, які викликають руйнування природного стану водних екосистем.

Під час оцінювання екологічного стану водойм особливої уваги варті дослідження донних відкладів річок, які дозволяють визначити ділянки акумуляції полютантів, а також виявити джерела їх надходження у водойми (Sharipova, 2015; Shykhalyeyeva et al., 2015). Накопичуючи приорітетні забруднювачі навколишнього середовища, донні відклади описують повноцінний вплив техногенезу на водні екосистеми. Вони служать своєрідною «пам'яттю», яка визначає особливості накопичення забруднюючих речовин у водному середовищі (Madzhd and Alexanrova, 2016). Для більшості гірських екосистем донні відклади, які складаються переважно 3 кам'янистих та піщаних порід із низьким вмістом органічної речовини, осадження важких металів починається із седиментації хімічних сполук із подальшим їх окисненням і переходом із розчинних закисних форм у важкорозчинні оксиди. Визначальними чинниками у процесах міграції важких металів виступають гумінові кислоти та фульвокислоти, які не тільки беруть учать у зв'язуванні іонів важких металів, а і знижують їх токсичний ефект (Kolesnyk, 2014). Седиментація мікроелементів на дно водойми сприяє очищенню води від екотоксикантів i, водночас, забрудненню донних відкладів. Вторинне забруднення водойми відбувається при переході токсикантів у водну товщу, i цьому передує низка процесів, серед яких розчинення та десорбція, що регулюють вміст накопичених елементів у донних відкладах, а також їх змучування, що особливо характерно для гірських річок у паводковий період (Rabajczyk, 2012).

Комплексні дослідження в системі «вода - донні відклади» повноцінно відображають порушення рівноваги у гідроекосистемі, що в результаті дозволяє адекватно оцінити екологічний стан водойми. Найбільшим кумулятивним ефектом володіють важкі метали, які, на відміну від органічних речовин, не піддаються деструкції, а тільки змінюють свій фізико-хімічний стан, мігруючи між компонентами водної екосистеми. Здатність донних відкладів до акумуляції полютантів різної природи однин із шляхів самоочищення водойм i, водночас, потенційне джерело забруднення через перерозподіл забруднюючих речовин у водну товщу (Madzhd and Aleksandrova, 2016).

Надхоження екотоксикантів із донних відкладів зумовлене низкою гідродинамічних та хімічних чинників, до яких належить збільшення швидкості течії, що перш за все властиве для лотичних екосистем; зміна температури, $\mathrm{pH}$ і окисно-відновних процесів (Konovets et al., 2013).

3 огляду на наведене вище, мета цієї статтї - оцінити вміст важких металів у річці Уж на територіях із різним рівнем антропогенного навантаження протягом весняно-літнього періоду.

\section{Матеріал і методи досліджень}

Експериментальні дослідження включали комплексне визначення хімічних елементів у воді та донних відкладах. Проби води та донних відкладів відбирали до та нижче міста Ужгород (48³8'28.5" N, 22²0’48.5" E - 48³7’10.2" N, 22¹5’26.4" E),

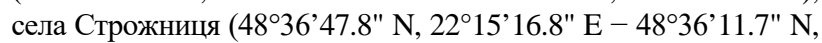
$22^{\circ} 12^{\prime} 18.3^{\prime \prime}$ Е) та міста Перечин (4844’59.9" N, 22³0’53.1" Е 4844’59.9" N, 22³0’53.1" Е), а також у 100 м від місця впадіння струмка Доморадж у р. Уж (4843’37.1" N, 22²8’42.1" Е). Фонові зразки відібрано на території, яка найменш потерпала від людської діяльності, - вище с. Волосянка (4859’07.3" N, 2250’01.7" Е). Дослідження проводили упродовж квітня травня та червня - липня 2016 року. Відбирання проб води проведене 3 поверхневого горизонту середини водойми за до-

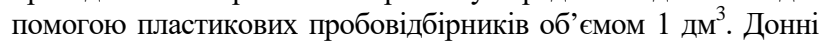
відклади відбирали згідно з ГОСТ 17.1.5.01.80, з урахуванням морфології русла річки. Аналіз води та донних відкладів здійснювали на емісійному спектрометрі на ICP-MS «Agilent 7700x». Донні відклади аналізували після озолення наважок азотною кислотою за допомогою мікрохвильової системи пробопідготовки Milestone Start D. Розчини готували на воді I класу (18 Мом), підготовленою на системі очищення води Scholar-UV Nex Up 1000 (Human Corporation, Корея). Як калібрувальні стандарти використовували розчини Multielement standard solution 5 for ICP (Fluka).

Найбільша мережа річкових систем характерна для Закарпатської області та складається з 152 річок, довжина яких понад 10 км. На особливу увагу заслуговує одна з головних річок Закарпаття - Уж, яка належить до басейну річки Тиси (ліва притока Дунаю). Уж бере свій початок неподалік Ужоцького перевалу та впадає в річку Лаборець, що на території Словаччини. Протяжність водойми в межах області становить 112,8 км, а площа водозбору -1582 км$^{3}$. Річище помірно розгалужене, 3 невисокими водоспадами. Похил річки - 7,2 м/км, ширина переважно 15-30 м. Гідробіологічні особливості даної водойми зумовлюють її поділ на три частини: верхню - гірську, середню - передгірну та нижню - низинну, де річка набуває рівнинного типу (Nikolaichuk et al., 2015).

За статусом річка Уж належить до міжнародних водотоків, а також $є$ одним 3 основних джерел питного водопостачання як для обласного центру, так і для прилеглих сіл. Тож проведення низки комплексних досліджень щодо просторової оцінки екологічного стану річки Уж - вагома складова забезпечення контролю над унікальними природними екосистемами Карпат.

У даній статті проби води та донних відкладів аналізували на вміст окремих хімічних елементів. Отримані показники порівняно 3 нормативами: для води - із ГДК для рибогосподарських водойм, для донних відкладів - із ГДК грунтів і 3 фоновими показниками. Концентрацію (С) металів у воді виражали у мкг/дм, у донних відкладах - у мг/кг.

Майже по всій протяжності річка Уж підпадає під антропогенний тиск, оскільки протікає між населеними пунктами, на їі берегах розташовані сільськогосподарські угіддя, неподалік проходять автомагістралі та залізничні шляхи, об’єкти деревообробної та лісохімічної галузей. Найменш ураженою залишається територія в межах витоку річки, освоєння якої обмежене через гірський рельєф і лісистість. Таким чином, через значне 
просторове розміщення потенційних джерел антропогенного забруднення обрано такі ділянки (рис. 1):

1) рекреаційна, що на території витоку річки;

2) техногенно-трансформована (знаходиться в межах міста Перечин, де розміщений Перечинський лісохімічний комбінат);

3) урбанізована (охоплює територію міста Ужгород і прилеглих сіл);

4) аграрна (розташована в районі с. Сторожниця, де зосереджена значна кількість сільськогосподарських угідь і фермерських господарств).

\section{Результати}

Середній валовий вміст хімічних елементів у воді річки Уж на територіях із різним рівнем антропогенного навантаження наведено в таблиці 1.

За результатами мас-спектрометричного аналізу води встановлено перевищення нормативних показників для водойм рибогосподарського призначення серед хімічних елементів, які належать до маркерів екологічного забруднення. Упродовж весняного періоду концентрації купруму перевищували гранично допустимі норми від 2 до 10 разів у районі техногенно трансформованої території (створи 3 та 4), на урбанізованих просторах - у 2,0-2,5 раза (створи 5 та 6), аграрній місцевості - у 3,8-5,0 раза (створи 7 та 8). Підвищений вміст міді зафіксовано й у літні місяці, де у створах 3 та 4 нормативні значення перевищені в 5,1 та 2,6 раза, на урбанізованій території - в 2,0-2,4 раза у створах 5 і 6 . На аграрній території концентрації міді в літню пору виявилися нижчими, ніж навесні, проте перевищували ГДК в 2,7 та 3,2 раза у створах 7 та 8 . Подібний просторовий розподіл характерний і для цинку, наднормативні значення якого зафіксовано у зоні промислового напруження та перевищують ГДК у 1,5-4,0 раза (створи 3 та 4) навесні та влітку в $1,1-4,5$ раза у створах 3 та 4 . У районі аграрної території упродовж квітня - травня виявлено перевищення арсену в 1,5 раза (створ 8), що більше за фоновий показник у 3,5 раза. Протягом літнього періоду перевищення ГДК сягало 1,0-1,4 раза у створах 7 та 8. Вміст ванадію у воді виявився незначним, хоча і перевищував ГДК упродовж квітня - травня в напрямку за течією річки. Також встановлено невисокі концентрації нікелю та плюмбуму по всій протяжності річки Уж. Найвищі показники хрому зосереджені на техногенно трансформованій території та перевищують фонові показники від 18-4,7 раза навесні та 3,1-5,9 раза влітку (створи 3 та 4), на урбанізованій від 1,4 до 1,8 раза (створи 5 і 6), аграрній - від 1,9 до 3,8 раза навесні (створи 7 та 8). Улітку показники хрому в районах урбанізованої та аграрної територій не перевищували фонових значень у значних межах.

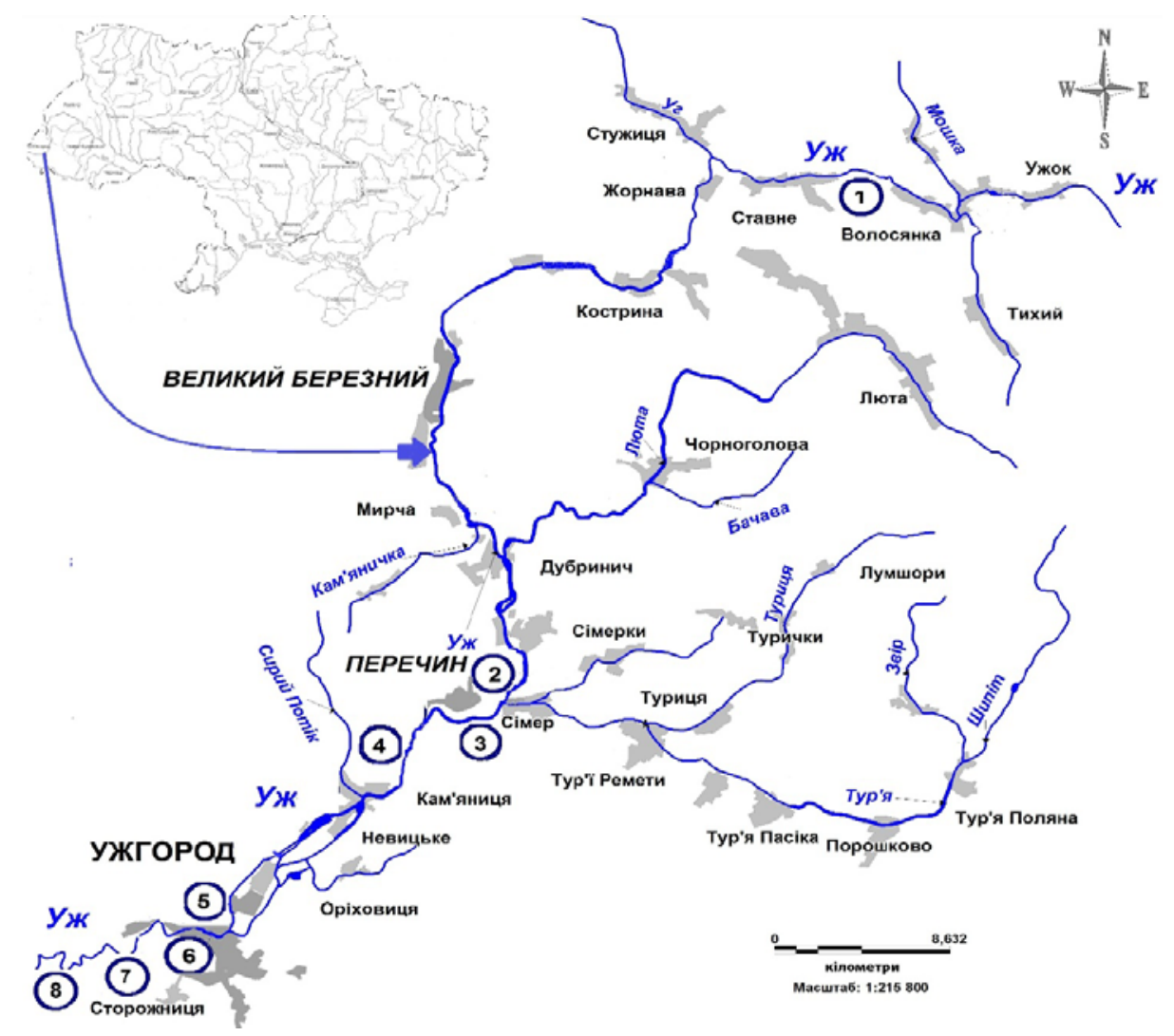

Рис. 1. Картосхема досліджуваних ділянок річки Уж $(\mathrm{n}=4): 1$ - рекреаційна територія, 2 - на початку с. Перечин,

3- 100 м нижче впадіння струмка Доморадж, 4 - за с. Перечин (техногенно трансформована територія), 5- до м. Ужгород, 6 - за м. Ужгород (урбанізована територія), 7 - до с. Сторожниця, 8 - за с. Сторожниця (аграрна територія)

Результати дозволяють припустити, що найбільші концентрації важких металів на техногенно трансформованій території, де зафіксовані перевищення ГДК і фонових значень серед таких полютантів, як $\mathrm{Cu}, \mathrm{Cr}, \mathrm{Zn}$. Дещо нижчі концентрації металів, які перевищують нормативи, виявлено у воді упродовж весняного періоду в напрямі до пониззя річки, де переважають значення $\mathrm{Cr}, \mathrm{V}, \mathrm{Cu}$, та As. Улітку перевищення нормативів зафіксовано тільки для Аs та Сu. Зразки проб води, відібрані з урбанізованої території, виявилися забрудненими ванадієм та міддю.

Визначення вмісту важких металів у донних відкладах дозволяє виявити приорітетні забруднювачі навколишнього сере- довища. Середній вміст валових форм важких металів у відібраних зразках намулу коливався у значних межах, перевищуючи фонові значення, однак наднормових концентрацій, які б перевищували ГДК грунту, виявлено не було. Порівняно з фоновими показниками у відібраних зразках намулу на техногенно трансформованій території виявлено значні концентрації таких важких металів: $\mathrm{Cu}, \mathrm{Ni}, \mathrm{Cr}$ та V (рис. 2).

Найвищі концентрації металів зафіксовано в точці 3. Показники нікелю тут сягали 6,5 мг/кг навесні та 7,1 мг/кг влітку, що в 5,4 та 6,4 раза більше, ніж фонові значення. Вміст хрому також коливався у значних межах, перевищуючи фонові кон- 
центрації в 11,3 раза (8,2 мг/кг) навесні та у 8,2 (7,8 мг/кг) влітку. Подібна ситуація склалася і 3 цинком, підвищений вміст якого у весняні місяці складав 9,1 мг/кг, а впродовж літа становив 4,1 мг/кг, що в 2,9 та 1,8 раза більше фонового вмісту.
До того ж на техногенно трансформованій території упродовж квітня - травня помічено зростання концентрацій ванадію, яке максимальне в точці 4 (3,1 мг/кг) і перевищує фонові значення в 5,2 раза.

\section{Таблиця 1}

Середні концентрації важких металів і рН води річки Уж (пункти відбору проб води 1-8) на територіях із різним характером антропогенного навантаження $(\mathrm{M} \pm \mathrm{m}, \mathrm{n}=4$, мкг/дм)

\begin{tabular}{|c|c|c|c|c|c|c|c|c|c|}
\hline & Місяці & 1 & 2 & 3 & 4 & 5 & 6 & 7 & 8 \\
\hline \multirow{2}{*}{$\mathrm{pH}$} & IV-V & $7,4 \pm 0,09$ & $7,3 \pm 0,15$ & $6,5 \pm 0,20$ & $6,4 \pm 0,11$ & $7,5 \pm 0,09$ & $7,7 \pm 0,22$ & $7.6 \pm 0,18$ & $8,1 \pm 0,18$ \\
\hline & VI-VII & $7,2 \pm 0,07$ & $7,1 \pm 0,17$ & $6,7 \pm 0,16$ & $6,8 \pm 0,21$ & $7,3 \pm 0,08$ & $7,5 \pm 0,11$ & $7,3 \pm 0,17$ & $7,9 \pm 0,21$ \\
\hline \multirow{2}{*}{$\mathrm{Pb}$} & IV-V & $3,0 \pm 0,75$ & $2,1 \pm 0,20$ & $7,0 \pm 0,31$ & $5,4 \pm 0.08$ & $5,1 \pm 0,14$ & $1,8 \pm 0,27$ & $3,3 \pm 0,34$ & $5,0 \pm 0,32$ \\
\hline & VI-VII & $3,2 \pm 0,22$ & $2,8 \pm 0,11$ & $9,8 \pm 0,13$ & $6,1 \pm 0,20$ & $5,8 \pm 0,19$ & $8,3 \pm 0,14$ & $7,8 \pm 0,33$ & $7,3 \pm 0,52$ \\
\hline \multirow{2}{*}{$\mathrm{Cr}$} & IV-V & $1,2 \pm 0,10$ & $0,7 \pm 0,11$ & $5,2 \pm 0,15$ & $2,1 \pm 0,14$ & $2,1 \pm 0,24$ & $1,6 \pm 0,24$ & $2,1 \pm 0,24$ & $4,2 \pm 0,34$ \\
\hline & VI-VII & $1,2 \pm 0,20$ & $1,3 \pm 0,16$ & $7,1 \pm 0,35$ & $3,8 \pm 0,23$ & $1,2 \pm 0,10$ & $1,4 \pm 0,14$ & $1,3 \pm 0,16$ & $1,2 \pm 0,17$ \\
\hline \multirow{2}{*}{$\mathrm{Ni}$} & IV-V & $5,2 \pm 0,10$ & $6,3 \pm 0,20$ & $6,5 \pm 0,15$ & $7,3 \pm 0,17$ & $6,2 \pm 0,17$ & $4,8 \pm 0,26$ & $3,1 \pm 0,45$ & $4,7 \pm 0,38$ \\
\hline & VI-VII & $4,2 \pm 0,23$ & $5,5 \pm 0,21$ & $9,2 \pm 0,21$ & $8,4 \pm 0,16$ & $7,5 \pm 0,18$ & $6,8 \pm 0,29$ & $4,3 \pm 0,24$ & $3,6 \pm 0,33$ \\
\hline \multirow{2}{*}{$\mathrm{Cu}$} & IV-V & $1,0 \pm 0,10$ & $0,9 \pm 0,13$ & $10 \pm 1,37$ & $2,1 \pm 0,21$ & $2,5 \pm 0,35$ & $2,0 \pm 0,23$ & $3,8 \pm 0,36$ & $5,1 \pm 0,27$ \\
\hline & VI-VII & $1,0 \pm 0,11$ & $1,0 \pm 0,10$ & $5,1 \pm 0,27$ & $2,6 \pm 0,20$ & $2,0 \pm 0,13$ & $2,4 \pm 0,17$ & $2,7 \pm 0,27$ & $3,2 \pm 0,20$ \\
\hline \multirow{2}{*}{$\mathrm{Zn}$} & IV-V & $10,2 \pm 1,00$ & $12,0 \pm 1,49$ & $41,0 \pm 1,75$ & $15,0 \pm 1,08$ & $8,1 \pm 0,25$ & $1,9 \pm 0,36$ & $2,7 \pm 0,42$ & $4,4 \pm 0,35$ \\
\hline & VI-VII & $9,0 \pm 0,70$ & $8,0 \pm 2,04$ & $45 \pm 2,04$ & $11 \pm 1,47$ & $5,4 \pm 0,29$ & $2,3 \pm 0,18$ & $2,5 \pm 0,34$ & $2,9 \pm 0,16$ \\
\hline \multirow{2}{*}{ As } & IV-V & $2,2 \pm 0,13$ & $0,8 \pm 0,10$ & $2,5 \pm 0,14$ & $3,2 \pm 0,19$ & $2,0 \pm 0,14$ & $4,5 \pm 0,57$ & $2,5 \pm 0,34$ & $7,4 \pm 0,27$ \\
\hline & VI-VII & $2,5 \pm 0,15$ & $2,4 \pm 0,20$ & $4,6 \pm 0,36$ & $4,0 \pm 0,28$ & $3,8 \pm 0,36$ & $4,8 \pm 0,31$ & $5,3 \pm 0,30$ & $6,8 \pm 0,36$ \\
\hline \multirow{2}{*}{$\mathrm{V}$} & IV-V & $0,7 \pm 0,12$ & $0,6 \pm 0,10$ & $1,9 \pm 0,12$ & $1,9 \pm 0,23$ & $2,0 \pm 0,29$ & $1,5 \pm 0,14$ & $1,9 \pm 0,13$ & $1,9 \pm 0,10$ \\
\hline & VI-VII & $0,8 \pm 0,10$ & $0,9 \pm 0,13$ & $0,9 \pm 0,12$ & $0,9 \pm 0,14$ & $0,9 \pm 0,10$ & $0,8 \pm 0,15$ & $0,8 \pm 0,14$ & $0,8 \pm 0,16$ \\
\hline
\end{tabular}

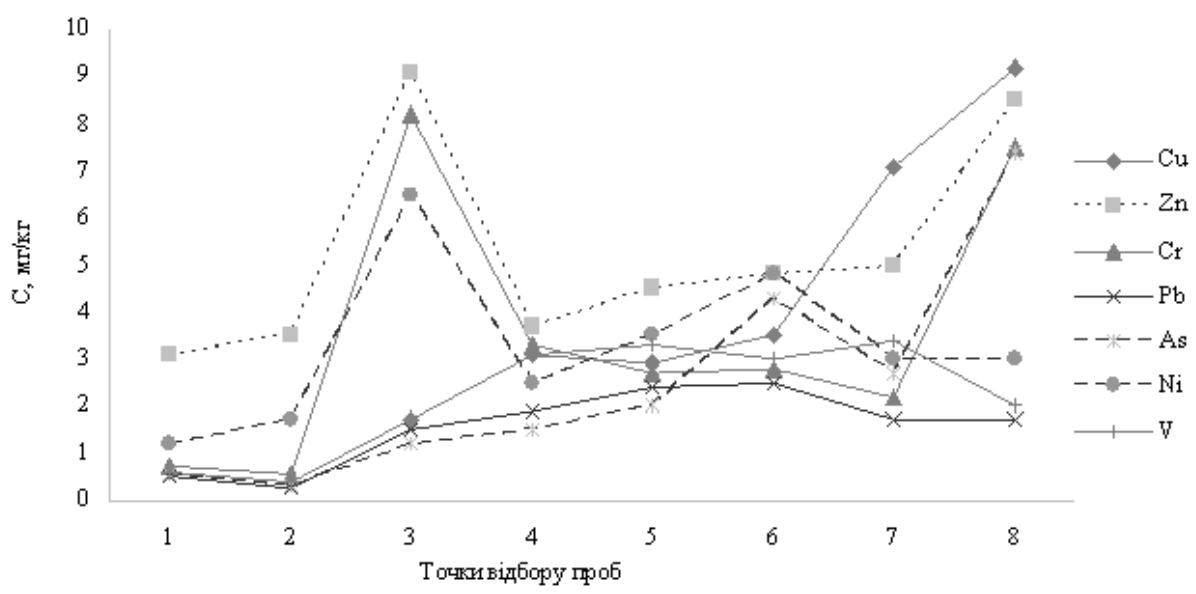

Рис. 2. Середній вміст важких металів у донних відкладах річки Уж (весняний період)

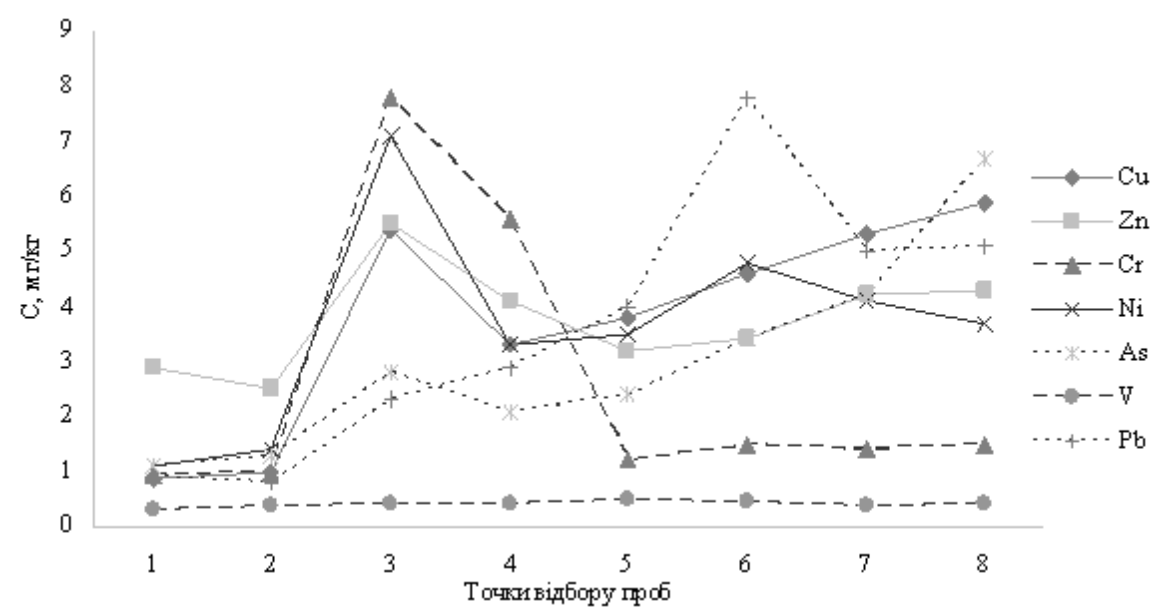

Рис. 3. Середній вміст важких металів у донних відкладах річки Уж (літній період)

У зразках намулу, відібраних у районі урбанізованої території, виявлено підвищений вміст $\mathrm{Ni}, \mathrm{Pb}$ i Cu. Концентрації купруму упродовж квітня - травня коливалися в межах від 4,7 мг/кг (точка 5) до 7,3 мг/кг (точка 6), що в 6,0 та 9,3 раза перевищує фонові показники. У літні місяці вміст купруму був дещо нижчим і складав 3,8 мг/кг на початку урбанізованої території та 4,6 мг/кг за ії межами, що перевищувало фоновий вміст у 4,4 та в 5,3 раза відповідно. Щодо плюмбуму, то його найвищі концентрації виявлені влітку за містом Ужгород -
7,8 мг/кг, а це в 8,4 раза більше, ніж фонові значення. Подібну тенденцію спостерігаємо і до зростання нікелю, найвищі показники якого також зафіксовані в літній період і становлять 4,8 мг/кг, що у 4,1 раза більше природного фону. Донні відклади аграрної території виявилися збагаченими на $\mathrm{Cu}, \mathrm{Zn}$ i As. У пониззі водойми акумуляція міді весною сягала максимуму, перевищуючи фонові значення від 9,1 (точка 7) до 11,7 (точка 8) раза. Улітку показники зменшилися до 5,3 та 5,9 мг/кг, що в 6,0 та 6,7 раза більше фону. Порівняно з урбанізованою 
територією, зросли концентрації арсену (7,4 мг/кг) та хрому $(8,1 \mathrm{мг} / к г)$, які протягом весни перевищують фонові значення As y 13,5 раза, Cr в 10 разів в точці 8. Упродовж літніх місяців спостерігаємо зменшення концентрації цих елементів, вміст арсену становить 6,7 мг/кг, що в 6 разів більше фонових показників, хрому - 1,5 мг/кг, що в 1,6 раза більше еталонних значень. Вміст цинку також збільшується навесні (5,0-8,5 мг/кг) і знижується влітку (4,1-4,3 мг/кг) у точках 7 та 8 .

Отримані дані вказують на значне накопичення хрому та нікелю в донних відкладах техногенно трансформованої території, а також купруму, цинку та арсену в районі аграрної території, що свідчить про потенційну небезпеку забруднення водойми даними металами.

На основі одержаних результатів розраховано коефіцієнти донної акумуляції (КДА) важких металів, які характеризують відношення концентрації токсикантів у донних відкладах до вмісту полютантів у воді та розраховуються за формулою:

$$
\mathrm{KД}=\frac{\mathrm{K}_{\text {д }}}{\mathrm{K}_{\mathrm{B}}} ;
$$

де $\mathrm{K}_{\text {д }}$ - концентрація забруднювача у донних відкладах, $\mathrm{K}_{\text {в }}$ концентрація забруднювача у воді (Miroshnichenko, 2014; Shytikov et al., 2003).

Величина КДА залежить від низки чинників: природи потенційного забруднювача та його розчинності у воді, а також гідроморфологічних особливостей водного об'єкту. Зменшення коефіцієнтів концентрації свідчить про зниження рівня забруднення та активізацію процесів детоксикації, а зростання, навпаки, вказує на інтенсивне забруднення водної екосистеми (табл. 2).

Коефіцієнти накопичення дозволяють виявити найважливіші потенційні забруднювачі водної екосистеми, здатні переходити у водну фазу під час зміни гідродинамічних (збільшення швидкості течії, вітрове перемішування водних мас) і фізи- ко-хімічних (температура, $\mathrm{pH}$, окислювально-відновні процеси) умов, спричиняючи вторинне забруднення гідроекосистем.

У відібраних зразках донних відкладів встановлено КДА для важких металів, виявлені навесні та влітку 2016 року. У весняну пору (рис. 4) в межах техногенно трансформованої території у значних кількостях акумулюються $\mathrm{Cr}$ та $\mathrm{Ni}$ в 100 м від скиду промислових стічних вод (точка 3), трохи нижче течії вміст нікелю знижується, натомість зростає коефіцієнт накопичення для купруму, ванадію та хрому (точка 4).

\section{Таблиця 2}

Оцінка ступеня токсичного забруднення поверхневих вод за КДА (за Shytikov et al., 2003)

\begin{tabular}{cccc}
\hline \multicolumn{1}{c}{ Показник } & $\begin{array}{c}\text { Екологічна } \\
\text { криза }\end{array}$ & $\begin{array}{c}\text { Надзвичайна } \\
\text { екологічна } \\
\text { ситуація }\end{array}$ & $\begin{array}{c}\text { Відносно } \\
\text { задовільна } \\
\text { ситуація }\end{array}$ \\
\hline $\begin{array}{l}\text { Коефіцієнт донної } \\
\text { акумуляції (КДА) }\end{array}$ & понад $10^{4}$ & $10^{3}-10^{4}$ & до $10^{3}$ \\
\hline
\end{tabular}

У районі урбанізованої території, де річка набуває рівнинного характеру, акумуляція важких металів у намулі зростає, зокрема надалі збільшується накопичення купруму, а вміст ванадію та хрому, хоч і зменшується, та все ж залишається на високих позначках (точка 5). За найбільш густонаселеною територією, через яку протікає річка Уж (точка 6), зафіксовано високий ступінь акумуляції серед таких полютантів, як $\mathrm{Cu}, \mathrm{Zn}$, $\mathrm{Cr}$ i V, що вказує на прогресуючий рівень забруднення на даній дослідній ділянці. Униз за течію річки при переході на аграрну територію вміст ванадію в донних відкладах значно зменшується, високими залишаються коефіцієнти для міді, хрому та цинку (точка 7). Вплив сільськогосподарської діяльності у пониззі річки відображається накопиченням арсену в донних відкладах, а також збільшенням хрому та цинку в точці 8.

Влітку акумуляція майже всіх досліджуваних елементів знижується по всій протяжності річки Уж (рис. 5).

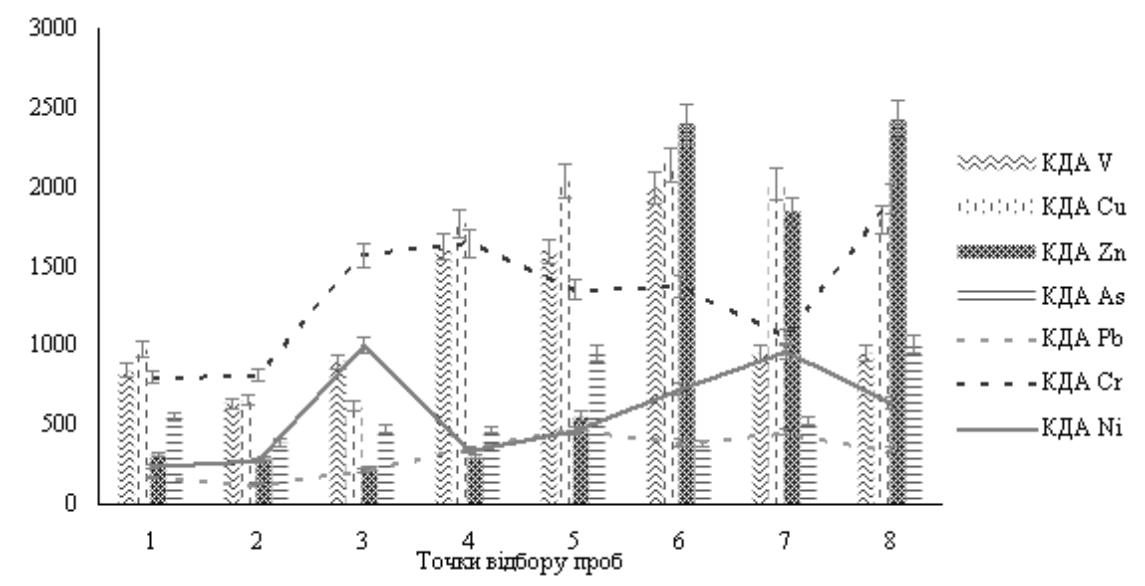

Рис. 4. Коефіцієнти донної акумуляції важких металів у річці Уж (весняний період 2016 р.)

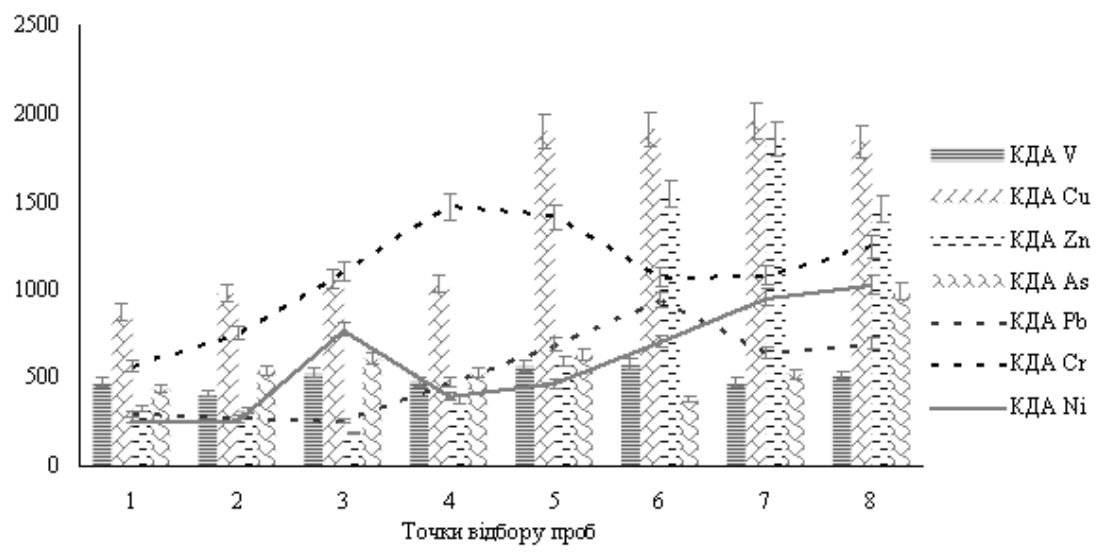

Рис. 5. Коефіцієнти донної акумуляції важких металів у річці Уж (літній період 2016 р.) 
У межах рекреаційної території виявлено зниження рівня накопичення таких елементів, як V та As (порівняно $з$ весняними показниками). На техногенно трансформованій території виявлено зростання акумуляції купруму в донних відкладах точок 2 і 3, яке далі за течією річки знижується порівняно 3 весняними значеннями. Подібна динаміка спостерігається 3 накопиченням арсену, вміст якого влітку збільшується тільки в межах техногенно трансформованої території. Значення КДА для хрому упродовж червня - липня виявилося найвищим у точці 4, тоді як навесні коефіцієнт був значним вище за течією в точці 3. Улітку акумуляція плюмбуму збільшується по всій водоймі, а особливо в точці 6 , що за межами міста. Вміст ванадію в літній період коливається в сталих межах по всій течії річки, значно зменшуючись порівняно з весняними показниками.

Коефіцієнт накопичення цинку також зменшується в літній період, проте динаміка розповсюдження елементу залишається незмінною. За допомогою розрахунку коефіцієнтів донної акумуляції можна зробити висновок, що найнебезпечніші полютанти даної водойми - купрум, хром і цинк, які накопичуються у донних відкладах майже по всій річці.

\section{Обговорення}

Купрум - широко розповсюджений хімічний елемент. У вільному стані зустрічається рідко, в основному знаходиться у земній корі у вигляді сульфідів. До основних мідних мінералів належить халькозин $\mathrm{Cu}_{2} \mathrm{~S}$, борніт $\mathrm{Cu}_{5} \mathrm{FeS}_{4}$ i халькопірит $\mathrm{CuFeS}_{2}$, прояви яких зустрічаються на території Закарпатської області. У водному середовищі купрум може міститися у різних формах: вільній (у вигляді гідратованого іона) та закомплексованій (з неорганічними та органічними лігандами), що і визначає ступінь його токсичності. Закомплексована мідь володіє меншим токсичним ефектом, ніж вільні іони металу. Однак токсичність купруму підвищується за наявності значних концентрацій кадмію, цинку або ж нікелю, а за присутності кальцію поріг токсичності знижується. Надходження міді у природні води може проходити із зовнішнього середовища або ж унаслідок внутрішньоводоймних процесів. Основними джерелами техногенного надходження металу у водні екосистеми виступають стічні води металургійної та хімічної промисловості, шахтні стоки мідних рудників, продукти корозії мідних об'єктів, внесення альгоцидних препаратів і багато інших (Seker and Kutlu, 2014).

Навесні вміст купруму сягав високих значень у водоймі урбанізованої та аграрної території, що, ймовірно, спричинено надходженням металу разом із комунально-побутовими та сільськогосподарськими стоками. Час проведення досліджень співпав із періодом активної хімізації сільськогосподарських земель, тому внесення мінеральних добрив, а особливо використання засобів боротьби зі шкідниками могло зумовити підвищення концентрацій міді у поверхневих водах. У літній період концентрації міді у річковій воді дещо зменшуються, що може бути пов'язано з періодом активної вегетації фітогідробіонтів, який супроводжується підлуговуванням води та збагаченням iï киснем, що викликає окиснення металу та його подальше осадження на дно. У районі техногенно трансформованої території вміст купруму у поверхневих водах сягає наднормативних значень і залишається майже незмінним протягом весняно-літнього періоду, прослідковується тільки незначне зниження металу в літні місяці. Подібна тенденція свідчить про регулярне надходження полютанту у поверхневі води, джерелом якого можуть бути неконтрольовані скиди промислових і комунально-побутових стічних вод.

У донних відкладах досліджуваної річки купрум акумулюється в значних межах, найбільший вміст зосереджено в районі урбанізованої та аграрної території. Значне накопичення міді може носити як природній, так і техногенний характер. У даній місцевості річка переходить із гірського до рівнинного типу, $\mathrm{i}$ після весняних дощів на рівнинні території з водними масами переноситься значна кількість органічних речовин природного походження, залишки рослин і рештки відмерлих тварин, які утворилися ще у зимовий період. Це сприяє зростанню закомплексованих форм міді в результаті накопичення в донних відкладах. Техногенне забруднення донних відкладів урбанізованої та аграрної територій найімовірніше спричинене змивом токсикантів із прилеглих територій, особливо у період весняних паводків, коли значна кількість забруднювачів мігрує 3 грунтів у донні відклади. Улітку вміст міді у донних відкладах рівнинних територій дещо знижується, що зумовлено певними гідрохімічними особливостями досліджуваної річки або ж зменшенням антропогенного тиску. На техногенно трансформованій території найбільше накопичення елементу у весняний період зафіксоване за межами міста Перечин, що зумовлене значними концентраціями полютанту у воді нижче скиду промислових вод. Можна припустити, що мідь, потрапивши у водойму, переноситься за рахунок швидкісної течії та осаджується на дно на значній відстані від джерела надходження. Улітку накопичення металу зростає в точці 3, що може бути пов'язане як $з$ природними, так і $з$ антропогенними чинниками: літній меженний період супроводжується зменшенням швидкості течії та інтенсифікацією процесів осадження. Тому одним із джерел надходження міді можуть служити процеси руйнування гірських порід. А техногенне надходження може бути зумовленим скиданням промислових стоків, які через повільно накопичуються.

Цинк належить до малотоксичних елементів. У вільному стані у природі не зустрічається, утворюючи мінерали: сфалерит $\mathrm{ZnS}$, смітсоніт $\mathrm{ZnCO}_{3}$, вілеміт $\mathrm{Zn}_{2}\left[\mathrm{SiO}_{4}\right]$ та інші. Найбільше цинку міститься в поліметалічних рудах, де він зустрічається разом із мінералами свинцю та міді. У природні води потрапляє в результаті руйнування та розчинення гірських порід та мінералів. Антропогенне надходження металу зумовлене скиданням стічних вод із металургійних комбінатів, гальванічних цехів і збагачувальних підприємств (Linnik, 1986). Значна кількість токсиканту надходить з атмосферними опадами в результаті спалювання деревини. У поверхневих водах цинк знаходиться переважно у розчинній формі та у формі завислих часток, його зв'язування залежить від кількості гумусових речовин, які містяться у донних відкладах. При цьому ступінь закомлексованості металу з гумусовими речовинами зростає зі збільшенням $\mathrm{pH}$. У донних відкладах цинк проявляє високу міграційну здатність та швидко сорбується органічними речовинами які, у свою чергу, містять залізо, алюміній, марганець, кремній та інші елементи (Mur and Ramamurti, 1987).

Вміст цинку у воді досліджуваної річки виявився найвищим у районі техногенно трансформованої території. Оскільки високі показники елементу зафіксовані на незначній відстані від місця впадіння струмка в річку, то можна припустити, що основним джерелом його надходження служать стічні води лісохімічного комбінату, які поступають у водотік зі струмка Доморадж, що регулярно поповнюється відходами заводу. Проте на урбанізованій та аграрній територіях, розміщених нижче за течією річки, вміст цинку зменшується до допустимих значень. Найнижчі показники виявлені за межами населених пунктів, що, скоріше за все, пов'язано зі зростанням вмісту органічних речовин у цих ділянках через скидання комунально-побутових стічних вод (до 85 тис. м $^{3}$ /добу), що, ймовірно, спричиняє зв'язування метала у комплекси (Symkanich et al., 2015). Кращому засвоєнню мікроелемента сприяє перехід до низинних територій зі сповільненою течією та інтенсивно розвиненою рослинністю (Prokopchuk and Hrubinko, 2016). Улітку можна спостерігати зменшення вмісту цинку у воді по всій річці, що пояснюється активним споживанням мікроелементу водною біотою.

Найбільша акумуляція цинку в донних відкладах зосереджена у пониззі річки (урбанізована та аграрна території). Подібна просторова динаміка може бути спричинена, по-перше, вимиванням металу з гірських порід і перенесенням на значні 
відстані у період весняного повноводдя 3 подальшим осадженням на дно. По-друге, значна замуленість низинних територій підвищує рівень закомплексованості цинку за рахунок збільшення гумусових речовин у донних відкладах. По-третє, зв’язуванню металу сприяє збільшення водневого показника у водному середовищі, що характерно для літнього періоду (Linnik, 1986). У донних відкладах техногенно трансформованої території виявлене незначне накопичення металу. Водневий показник на досліджуваних ділянках 3 та 4 навесні знаходився в межах 6,4-6,5, а влітку - 6,7-7,1, що могло сприяти вивільненню цинку з донних відкладів і подальшої міграції у воду.

Хром досить поширений у природі, трапляється у вигляді сполук із киснем, утворюючи алюмохроміт, магнохроміт, хроміт та інші мінерали. У водні екосистеми потрапляє в результаті вилуговування з гірських порід і грунтів, а також у процесі розкладання відмерлих решток рослин і тварин. Техногенними джерелами виступають викиди та стічні води текстильних та хімічних підприємств, зокрема лісохімічної промисловості, де як консерванти деревини використовують хромати та біхромати. Хром - потужний екотоксикант, який залежно від валентності може відігравати різноманітну роль у біохімічних процесах $\mathrm{i}$ проявляти різну токсикологічну дію. Потрапляючи у водойму, хром найбільше акумулюється в донних відкладах. Активно сорбуючись у мулі, метал часто стає причиною вторинного забруднення водних екосистем (Mur and Ramamurti, 1987).

У воді та донних відкладах досліджуваної водойми вищі концентрації хрому зафіксовано неподалік від злиття русла річки зі струмком Доморадж, що свідчить про надходження металу з промисловими стоками. В літню пору, а саме в меженний період, концентрації металу в районі техногенно трансформованої території зростають, що спричинено зменшенням швидкості течії та перемішування водних мас. Незначне підвищення вмісту хрому зафіксоване упродовж весняного періоду у пониззі річки, що пов'язано з високим рівнем урбанізації басейну на цих територіях, а також надходженням полютантів iз поверхневим стоком і комунально-побутовими стічними водами. Із віддаленням від техногенно трансформованої території акумуляція металу у донних відкладах зменшується. Подібне просторове розповсюдження хрому можна пояснити його низькою міграційною здатністю.

Плюмбум - один із найтоксичніших забруднювачів водних екосистем. У природі зустрічається у складі поліметалічних сульфідних руд. У поверхневі води надходить у результаті розчинення ендогенних (галеніти) та екзогенних (церусити, англезити) мінералів. Техногенне надходження в природне середовище обумовлене скиданням промислових стічних вод, виготовленням свинцево-кислотних акумуляторів, свинцевих фарб та викидами продуктів згорання кам'яного вугілля. Одне 3 основних джерел надходження свинцю - вихлопні гази автотранспорту, що містять тетраетилсвинець, який, попри заборону, ще й досі використовують для підвищення октанового числа. У водному середовищі зв'язування свинцю проходить зазвичай в умовах кислого середовища та значних концентрацій органічних речовин (Mur and Ramamurti, 1987).

У воді досліджуваних територій наднормативних концентрацій плюмбуму не зафіксовано, проте влітку виявлено тенденцію до збільшення концентрацію полютанту за містом порівняно $з$ фоновим показником. Подібне зростання вмісту елемента у водоймі відбувається внаслідок збільшення техногенного навантаження в районі урбанізованої території, де джерелом свинцю виступають викиди автотранспорту. Слід зазначити, що викид забруднюючих речовин автотранспортом зріс за останні десятиріччя, що пов'язано зі збільшенням кількості автотранспорту, який експлуатується в місті або ж щодня перетинає досліджувану територію через західний транспортний коридор у напрямі до Європи (Gabchak, 2007).

Накопичення свинцю протягом весняно-літнього періоду у донних відкладах зростало в міру наближення до урбанізованої території, сягаючи максимальних значень за містом. У районі аг- рарної території акумуляція екотоксиканту зменшувалася, що можливо за рахунок збільшення водневого показника та низької міграційної здатності елементу.

Нікель належить до умовно есенціальних елементів і, одночасно, відомий як потенційний екозабруднювач. Природними джерелами елементу виступають сульфідні мідно-нікелеві та силікатні нікелеві руди. Антропогенне забруднення в основному зумовлене спаленням дизельного пального, використання якого за останні роки зросло. До потужних джерел полютанта відносять підприємства кольорової металургії, гірничорудної промисловості, гальванотехнічні цехи, теплові електростанції, які працюють на кам’яному вугіллі, підприємства 3 виробництва акумуляторів та виплавлення сталі. Розподіл мікроелементу у водній екосистемі залежить від багатьох чинників, насамперед від $\mathrm{pH}$ середовища. Найбільша комплексотвірна здатність фульвокислот відносно нікелю проявляється за $\mathrm{pH}=6,0$ 7,0 а за його збільшення нікель переходить у гідрокомплекси (Yu and Tsunoda, 2004).

За весь період досліджень значних коливань полютанта у воді не виявлено, вміст нікелю був незначним, а в районі урбанізованої та аграрної територій навіть меншим за фоновий показник. Зниження концентрацій нікелю, ймовірно, пов’язане 3 його зв'язуванням у комплекси 3 фульвокислотами за $\mathrm{pH}$ навесні 6,4-7,7, а влітку - 6,8-7,9. При цьому у донних відкладах виявлені більші концентрації металу, зокрема на техногенно трансформованій території (точка 3), що може свідчити про давнє забруднення, джерело якого - промислові стоки. Суттєве зниження вміту металу виявлене нижче за течією - у точці 4 i, як наслідок, може бути викликане конкурентним зв’язуванням фульвокислот купрумом, уміст якого тут зростає, або ж просто зменшенням техногенного навантаження. За містом накопичення нікелю в донних відкладах знову зростає, що може бути спричинене надходженням металу з поверхневим стоком із прибережних автосмуг і залізничних полотен, прокладених паралельно до водотоку (Bobryk, 2015).

Арсен - металоїд, широко розповсюджений у земній корі. У навколишньому середовищі знаходиться у вигляді сірковмісних мінералів: реальгару (AsS), аурипігменту $\left(\mathrm{As}_{2} \mathrm{~S}_{3}\right)$, apceнопіриту (AsFeS) та інших. Процеси вивітрювання та вилуговування з арсеновмісних гірських порід - одні з основних причин природнього забруднення поверхневих вод. Серед техногенних чинників до найбільш потенційно небезпечних належать підприємства кольорової металургії, стічні води яких містять значні концентрації арсену. Виробництво фарб, пігментів, керамічних виробів із використанням токсиканту - також одне iз джерел забруднення навколишнього середовища. Арсеновмісні гербіциди, інсектициди, пестициди, які зазвичай надходять до водойм через поверхневий стік із сільськогосподарських угідь чи інших територій, часто стають причиною помітного забруднення (Mur and Ramamurti, 1987).

Арсен здатний проявляти мутагенну та канцерогенну дію щодо живих організмів. Його токсична дія передусім пов’язана зі здатністю заміщувати фосфор у біологічних сполуках i, як наслідок, змінювати хід біохімічних реакцій.

У річці Уж вміст арсену протягом весняно-літнього періоду коливався в межах гранично допустимих концентрацій, крім аграрної території. Найвірогідніше, що підвищений вміст металу на аграрній території спричинений інтенсифікацією використання сільськогосподарських отрутохімікатів, які містили сполуки арсену.

У донних відкладах накопичення екотоксиканту зростає 3 урбанізованої території, збільшуючись у напрямі до гирла річки. $\mathrm{y}$ цих районах річка протікає поблизу приватних секторів, тому основним джерелом забруднення тут можуть слугувати неконтрольовані скиди побутових стічних вод, що містять значну кількість мийних засобів, а деякі з яких, як відомо, вміщують у своєму складі миш'як. Найвищий показник акумуляції металу спостерігали упродовж квітня-травня в межах аграрної території, що пов'язуємо з піком обробки сільськогосподар- 
ських рослин. Одними з потенційних джерел надходження елементу тут можуть слугувати як арсеновмістні пестициди, так i десиканти, використання яких за останні роки зросло.

Ванадій - важкий метал, здатний проявляти високу токсичність за підвищених концентрацій. Зустрічається в комплексних поліметалічних рудах: мідних, уран-ванадієвих, титомагнетитових, свинцево-цинкових та інших. Екологічно найнебезпечнішим вважається надходження елементу разом із випарами бензину та мазуту, оскільки ванадій здавна використовується у виготовленні нафтопродуктів. Джерела забруднення також металургійна, машинобудівна, текстильна та лакофарбова промисловості. У природних водах знаходиться в низьких концентраціях 0,2-4,5 мкг/дм ${ }^{3}$ (Rubio-Arias et al., 2007). Найвищі концентрації ванадію, які коливаються в межах 17,7-48,8 мг/дм³, зафіксовано у поверхневих водах поблизу підніжжя гори Фудзі (Японії). Підвищений вміст елементу тут пояснюється результатом вулканічної активності місцевих гір (Aiuppa et al., 2003).

Упродовж квітня - травня вміст ванадію у поверхневих водах коливався в незначних межах, хоча дещо перевищував ГДК. Літературні дані свідчать про стабільно підвищений вміст ванадію у грунтах Закарпатської області, який становить 82 мг/кг у гірській місцевості та 100 мг/кг на рівнинних територіях (Fatieiev and Pashchenko, 2003). Збільшення концентрацій ванадію у воді та донних відкладах навесні, ймовірно, пов'язане 3 вимиванням елементу 3 грунтотвірних порід, високий вміст якого зосереджений, зокрема, в магматичних гірських породах. Цілком імовірне також техногенне надходження елементу, оскільки відомо, що ванадієві солі часто використовуються як фунгіциди, інсектициди та інші дезінфікувальні засоби. Улітку концентрації металу суттєво знизились як у воді, так і в донних відкладах, що пов’язано зі зменшенням водності та швидкості течії річки та, відповідно, винесенням елементу з порід. Серед важливих чинників виділяємо також підвищення водневого показника, що сприяє зв’язуванню металу, особливо на рівнинних ділянках у пониззі річки.

\section{Висновки}

Комплексне визначення вмісту важких металів у системі «вода - донні відклади» вказує на значний вплив рельєфної диференціації територій на розповсюдження важких металів у річці Уж. У межах гірських територій приорітетними забруднювачами виступають хром і нікель. Підвищений вміст цих металів як у воді, так і в донних відкладах техногенно трансформованої території - результат скидання промислових стічних вод. На рівнинній частині річки переважають високі концентрації купруму, ванадію та цинку. Джерелом ванадію служать абіотичні складові долини річки; це, зокрема, вулканічні гірські породи, які виникли в результаті вулканічної діяльності Карпатських гір. Високий уміст купруму та цинку зумовлений як екзогенним надходженням, так і наявністю у грунтотвірних породах із подальшим накопиченням через уповільнення течії. У межах аграрної території наявне забруднення арсеном, спричинене інтенсивним використанням арсенумістних сполук як сільськогосподарських отрутохімікатів. За результатами порівняльного аналізу досліджуваних територій найбільш забрудненими виявилася антропогенно трансформована територія та пониззя річки в межах аграрної, що свідчить про необхідність вдосконалення контролю під час здійснення моніторингу та оцінювання екологічного стану поверхневих вод.

\section{References}

Aiuppa, A., Bellomo, S., Brusca, L., D’Alessandro, W., \& Federico, C. (2003). Natural and anthropogenic factors affecting groundwater quality of an active volcano (Mt. Etna, Italy). Applied Geochemistry, 18(6), 863-882.

Al-Shami, S. A., Rawi, C. M., Ahmad, A. H., \& Nor, S. A. M. (2012). Genotoxicity of heavy metals to the larvae of Chironomuskiiensis Tokunaga after short-term exposure. Toxicology and Industrial Health, 28(8), 734-739.
Bo, L., Wang, D., Li, T., Li, Y., Zhang, G., Wang, C., \& Zhang, S. (2014). Accumulation and risk assessment of heavy metals in water, sediments, and aquatic organisms in rural rivers in the Taihu Lake region, China. Environmental Science and Pollution Research, 22(9), 6721-6731.

Bobryk, N. (2015). Poshyrennja ta akumuljacija vazhkyh metaliv u g'runtah pryzaliznychnyh terytorij [Spreading and accumulation of heavy metals in soils of railway-side areas]. Visnyk of Dnipropetrovsk University. Biology, Ecology, 23(2), 183-189 (in Ukrainian).

Brygadyrenko, V. V., \& Ivanyshyn, V. (2015). Changes in the body mass of Megaphyllum kievense (Diplopoda, Julidae) and the granulometric composition of leaf litter subject to different concentrations of copper. Journal of Forest Science, 61(9), 369-376.

Cirillo, T., Amodio Cocchieri, R., Fasano, E., Lucisano, A., Tafuri, S., Ferrante, M., \& Isani, G. (2011). Cadmium accumulation and antioxidant responses in Sparus aurata exposed to waterborne cadmium. Archives of Environmental Contamination and Toxicology, 62(1), 118-126.

Fatieiev, A., \& Pashchenko, Y. (2003). Fonovyi vmist mikroelementiv u gruntakh Ukrainy [Background content of microelements in Ukrainian soils]. National Science Centre, Kharkiv, 72 (in Ukrainian).

Fujita, M., Ide, Y., Sato, D., Kench, P. S., Kuwahara, Y., Yokoki, H., \& Kayanne, H. (2014). Heavy metal contamination of coastal lagoon sediments: Fongafale Islet, Funafuti Atoll, Tuvalu. Chemosphere, 95, 628-634.

Gabchak, N. (2007). Transportna merezha, ii stan i vplyv na pryrodne seredovyshhe Zakarpattja [Transport system, its state and influence on natural environment of Zakarpatt'a]. Naukovi Zapysky. Geografija, 2, $172-178$ (in Ukrainian).

Götze, S., Bose, A., Sokolova, I. M., Abele, D., \& Saborowski, R. (2014). The proteasomes of two marine decapod crustaceans, European lobster (Homarus gammarus) and Edible crab (Cancer pagurus), are differently impaired by heavy metals. Comparative Biochemistry and Physiology Part C: Toxicology and Pharmacology, 162, 62-69.

Grba, N., Neubauer, F., Sajnovic, A., Stojanovic, K., \& Jovancicevic, B. (2015). Heavy metals in neogene sedimentary rocks as a potential geogenic hazard for sediment, soil, surface and groundwater contamination (Eastern Posavina and Lopare Basin, Bosnia and Herzegovina). Journal of the Serbian Chemical Society, 80(6), 827-838.

Islam, M., Ahmed, M., Raknuzzaman, M., Habibullah-Al-Mamun, M., \& Islam, M. K. (2015). Heavy metal pollution in surface water and sediment: A preliminary assessment of an urban river in a developing country. Ecological Indicators, 48, 282-291.

Kolesnyk, N. (2014). Rozpodil vazhkyh metaliv sered komponentiv prisnovodnyh ekosystem (Ogljad) [Distribution of heavy metals among the components of freshwater ecosystems (Review)]. Ribogospodars'ka Nauka Ukrainy, 29, 35-54.

Konovets, I., Kipnis, L., Goncharova, M., Podrugina, A., \& Sytnyk., Y. (2013). Ekologo-toksykologichne doslidzhennja rivniv zabtudnennja vody ta donnyh vidkladiv r. Nyvka v rajoni aeroportu «Kyi'v» [Ecological and toxivological assessment of pollution lavels of water and sediments of Nivka river near the airport «Kiev»]. Ribogospodars'ka Nauka Ukraini, 24, 32-44.

Kul’bachko, Y. L., Didur, O. O., Loza, I. M., Pakhomov, O. E., \& Bezrodnova, O. V. (2015). Environmental aspects of the effect of earthworm (Lumbricidae, Oligochaeta) tropho-metabolic activity on the $\mathrm{pH}$ buffering capacity of remediated soil (steppe zone, Ukraine). Biology Bulletin, 42, 899-904.

Linnik, P. N. (1986). Formy mihratsii metalov v presnykh poverkhnostnykh vodakh [Forms of metal migration in fresh surface waters]. Hidrometeoizdat, Leningrad (in Russian).

Mohiuddin, K., Alam, M., Ahmed, I., \& Chowdhury, A. (2016). Heavy metal pollution load in sediment samples of the Buriganga river in Bangladesh. Journal of the Bangladesh Agricultural University, 13(2), 229-238.

Mur, D. \& Ramamurti, V. (1987). Tiazholye metaly v prirodnyh vodah. [Heavy metals in natural waters]. Mir, Moscow (in Russian).

Miroshnichenko, O. P. (2014). Migracija vazhkyh metaliv u vodnyh ob’ektah (na prykladi r. Udy) [Migration of heavy metals in the water objects (e.g. river Udy)]. Visnyk Harkivs'kogo Nacional'nogo Universitetu imeni V. N. Karazina. Ekologija, 1054, 91-94 (in Ukrainian).

Nikolaichuk, V. I., Vakerich, M. M., Shpontak, J. M., \& Karpu’k, M. K. (2015). Mozhlyvi ekologichno obgruntovani shljahy zberezhennja ta rozvitku Ukrajins'kyh Karpat [The current state of water resources of Transcarpathia]. Visnyk of Dnipropetrovsk University. Biology, Ecology, 23(2), 116-123 (in Ukrainian).

Prokopchuk, O. I., \& Grubinko, V. V. (2016). Vazhki metaly u malyh richkah Ternopil'shhyny z riznym rivnem antropichnogo navantazhennja [Heavy metals in the small rivers of Ternopil region under different types of anthropogenic pressure]. Visnyk of Dnipropetrovsk University. Biology, Ecology, 24(1), 173-181 (in Ukrainian).

Rabajczyk, A. (2012). The relationship between metal forms found in river bottom sediments and land development (review). In: Balkis, N. (ed.) Water pollution. InTech, Rijeka. Pp. 189-202. 
Rubio-Arias, H., Quintana, C. E., Wood, K., Saucedo, R. A., \& Bautista-Margulis, R. (2007). Vanadium and lithium contamination in freshwaters of the Conchos River in Chihuahua, Mexico. Environmental Health Risk, 4, 171-179.

Seker, S., \& Kutlu, B. (2014). Determination of copper (Cu) levels for rivers in Tunceli, Turkey. World Environment, 4, 168-171.

Sfakianakis, D. G., Renieri, E., Kentouri, M., \& Tsatsakis, A. M. (2015). Effect of heavy metals on fish larvae deformities: A review. Environmental Research, 137, 246-255.

Shakeri, A., Shakeri, R., \& Mehrabi, B. (2016). Contamination, toxicity and risk assessment of heavy metals and metalloids in sediments of Shahid Rajaie Dam, Sefidrood and Shirinrood Rivers, Iran. Environmental Earth Sciences, 75(8), 1-13.

Sharipova, O. A. (2015). Raspredelenie tjazhelyh metallov v donnyh otlozhenijah ozera Balhash v zavisimosti ot prirodnyh i antropogennyh faktorov [Distribution of heavy metals in bottom sediments of lake Balkhash depending on natural and anthropogenetic factors]. Vestnik Tomskogo Gosudarstvennogo Universiteta, 390(1), 225-230 (in Russian).

Shykhalyeyeva, G. N., Chursina, O. D., Shykhalyeyev, I. I., Kiryushkina, A. N., \& Kuzmina, I. S. (2015). Prostranstvennaja izmenchivost' tjazhelyh metallov v otlozhenijah sajzskoj chasti ust'ja Kujal'nika [Spatial variability of heavy metals in the sedimentations of the saus part of the Kuyalnik estuary]. Odesa National University Herald. Chemistry, 19(4), 59-69 (in Russian).
Shytikov, V. K., Rozenberg, G. S., \& Zynchenko, T. D. (2003). Kolychestvennaja gydroekologyja: Metody systemnoj identyfykacyi [Quantitative hydroecology: Identification methods system]. Instytut Ekologii Vólzhskogo Basséjna Rossíjskoj Akadémii Naưflolyatti (in Russian).

Symkanich, O., Kyndruck, K., Gluch, O., \& Sukharev, S. (2015). Rozpodil vmistu vazhkih metaliv u donnih vidkladah richki Uzh mezhah mista Uzhgorod [Distribution of heavy metals in the bottom sedimentations of the river Uzh in the territory of city Uzhorod]. Scientific Bulletin of the Uzhgorod University. Series Chemistry, 33, 72-76 (in Ukrainian).

Tsvetkova, N. M., Pakhomov, O. Y., Serdyuk, S. M., \& Yakyba, M. S. (2016). Biologichne riznomanittja Ukrajiny. Dnipropetrovs'ka oblast'. Grunty. Metaly u gruntah [Biological diversity of Ukraine. The Dnipropetrovsk region. Soils. Metalls in the soils]. Lira, Dnipropetrovsk (in Ukrainian).

Yu, C., Zhang, J., Wu, L., Liu, Y., \& Ge, G. (2015). Effects of heavy metal and nutrients on benthic microbial communities in freshwater sediment of Poyang Lake (China). Journal of Residuals Science and Technology, 12(2), 105-111.

Yu, M. H., \& Tsunoda, H. (2004) Environmental toxicology: Biological and health effects of pollutants. CRC Press, Boca Raton.

Zhu, J., Zhang, J., Li, Q., Han, T., Xie, J., Hu, Y., \& Chai, L. (2013). Phylogenetic analysis of bacterial community composition in sediment contaminated with multiple heavy metals from the Xiangjiang River in China. Marine Pollution Bulletin, 70, 134-139. 